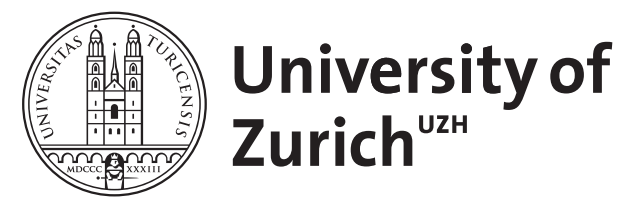

\title{
The state and fate of Himalayan glaciers
}

Bolch, Tobias ; Kulkarni, A ; Kääb, Andreas ; Huggel, Christian ; Paul, Frank ; Cogley, J G ; Frey, Holger ; Kargel, J S ; Fujita, K ; Scheel, M ; Bajracharya, S ; Stoffel, Markus

\begin{abstract}
Himalayan glaciers are a focus of public and scientific debate. Prevailing uncertainties are of major concern because some projections of their future have serious implications for water resources. Most Himalayan glaciers are losing mass at rates similar to glaciers elsewhere, except for emerging indications of stability or mass gain in the Karakoram. A poor understanding of the processes affecting them, combined with the diversity of climatic conditions and the extremes of topographical relief within the region, makes projections speculative. Nevertheless, it is unlikely that dramatic changes in total runoff will occur soon, although continuing shrinkage outside the Karakoram will increase the seasonality of runoff, affect irrigation and hydropower, and alter hazards.
\end{abstract}

DOI: https://doi.org/10.1126/science.1215828

Posted at the Zurich Open Repository and Archive, University of Zurich ZORA URL: https://doi.org/10.5167/uzh-72075

Journal Article

Originally published at:

Bolch, Tobias; Kulkarni, A; Kääb, Andreas; Huggel, Christian; Paul, Frank; Cogley, J G; Frey, Holger; Kargel, J S; Fujita, K; Scheel, M; Bajracharya, S; Stoffel, Markus (2012). The state and fate of Himalayan glaciers. Science, 336(6079):310-314.

DOI: https://doi.org/10.1126/science.1215828 


\section{Science \\ МIAAAS}

\section{Supporting Online Material for}

\section{The State and Fate of Himalayan Glaciers}

T. Bolch*, A. Kulkarni, A. Kääb, C. Huggel, F. Paul, J. G. Cogley, H. Frey, J. S. Kargel, K. Fujita, M. Scheel, S. Bajracharya, M. Stoffel.

*correspondence to: tobias.bolch@geo.uzh.ch

This PDF file includes:

SOM Text

Figs. S1 to S5

Tables S1 to S7

References 60 - 113 


\section{Supplementary Text}

\section{Current knowledge about glacier area and volume in the Himalaya and Karakoram}

Definitions of the H-K region vary, the chosen boundaries often being somewhat arbitrary. Peripheral mountain ranges, such as the Hindu Raj range in the northwest or Hengduan Shan in the east, are variously included or excluded. These variations hinder direct comparison of estimates of total glacier area and volume for the region, especially when the boundaries are not displayed. We subdivided the entire H-K region into the Karakoram, and the western, central and eastern Himalaya (Fig. 1 and S1). We hereby refer to (60) and (61) for a more detailed description and further information about the nature of the mountains and possible subdivisions.

The completeness and reference date of the data sets on which inventories are based vary strongly, both between and within inventories. For example, the first publicly available glacier inventory in the $\mathrm{H}-\mathrm{K}$ was completed by the International Centre for Integrated Mountain Development (ICIMOD) in 2001 and is based on map data from 1963 to 1982 and satellite imagery from $1999(39,62)$. Similarly, the first Chinese glacier inventory was only completed within 23 years of its inception (63). These inventories are downloadable from the database of the Global Land Ice Measurements from Space initiative (GLIMS, www.glims.org) (64).

In recent publications, the glacier coverage is often quoted from (3) as $33,050 \mathrm{~km}^{2}$ for the Himalaya and $16,600 \mathrm{~km}^{2}$ for the Karakoram. These numbers derive from (65) and (66), the latter being a global overview based on sources dating back to the $1950 \mathrm{~s}$. Hence, the numbers do not represent the recent glacier coverage and their accuracy is nearly impossible to assess.

A complete inventory for the Himalaya and Karakoram has been recently published (50). It is compiled from various sources (Chinese Glacier Inventory [CGI]; the older inventory by ICIMOD; and partial inventories of the Geological Survey of India [GSI]) and from newlydigitized glacier outlines for the Indian part of Kashmir, based on analog maps of the Soviet military (reference date: late 1970s; 1:200,000 scale). This inventory counts $\sim 21,000$ glaciers covering a total area of $\sim 43,200 \mathrm{~km}^{2}$ within the H-K region. Inventory dates cover 1968-2003. The author suggests, based on simple mass-budget projections, that up to $20 \%$ of the inventoried glaciers might have disappeared by 2010 (50). An overview of the discussed numbers for the glacier coverage of the $\mathrm{H}-\mathrm{K}$ region is compiled in Table S1.

\section{New estimates of glacier area, volume, and debris cover}

\subsection{New glacier inventory}

In order to present the most up-to-date number of glacier-covered area in the H-K region, we used the data from the new ICIMOD inventory based on Landsat ETM+ satellite data from around 2008 (67), an inventory for northwestern Himalaya generated from Landsat $\mathrm{ETM}+$ satellite data acquired between 2000 and 2002 within the framework of the ESA "GlobGlacier" project $(68,69)$, and data from parts of the Karakorum mapped by R. Bhambri using a Landsat ETM+ scene from 2002. Some remaining gaps mainly situated in Tibet/China were filled with data from the first Chinese Glacier Inventory (63) as available from the GLIMS data base (70, Fig. S1). Clean-ice glaciers were mapped automatically using band ratio images or the normalized difference snow index (NDSI). Both methods are based on the strong difference in spectral reflectance of ice and snow in the short-wave infrared compared the red or green band and separate ice and snow from other terrain with an appropriate threshold value following (71-73). While clean and also polluted ice can be mapped accurately from multispectral data using these methods (73-75), the debris-covered portions 
are still best mapped by manual digitization especially for smaller glaciers $(76,77)$. Further filters (e.g. for noise, surface slope, or vegetation) were in some regions applied to reduce the amount of misclassified pixels and to help to identify debris-covered glaciers $(67,78,79)$. To map the debris-covered parts accurately by visual methods, ALOS PALSAR coherence images $(69,80)$ were additionally considered. Glacier polygons smaller than $0.05 \mathrm{~km}^{2}$ were removed as they are subject to high uncertainties and do not add much to the total area and volume. The contiguous ice masses were split into their drainage basins using the SRTM3 digital elevation model (DEM) either fully manually or with the help of a watershed algorithm (75). These outlines were finally visually checked and manually improved if necessary.

The resulting total glacier area from this new assessment is $\sim 40,800 \mathrm{~km}^{2}$ (Table S2). Our best estimate of the percentage of debris-covered glacier area, based on measurements over an area of $32,000 \mathrm{~km}^{2}$, is $\sim 10 \%(12.6 \%$ and $9.6 \%$ in the Ganges and Indus basins, respectively) (67). This is of the same order as the estimate of $\sim 15 \%$ by (23) and the inventory for the northwestern Himalaya (69).

For all glaciers the minimum, maximum, and mean elevation, as well as mean slope were calculated by fusing the glacier polygons with the void-filled version 4 of the SRTM DEM, available from the Consultative Group on International Agricultural Research (CGIAR, http://srtm.csi.cgiar.org/).

\section{$\underline{2.2 \text { Glacier volume estimates }}$}

Glacier volumes were estimated by two different methods. One is based on the mean slope $(\alpha)$, the elevation range $(\Delta \mathrm{H})$ and the mean basal shear stress $(\tau)$ according to $(81)$. For this approach $\tau$ is parameterized in dependence of the elevation range and a constant value of 1.5 bar is applied if $\Delta \mathrm{H}$ exceeds $1.6 \mathrm{~km}(81)$. The resultant mass for all glaciers in $\mathrm{H}-\mathrm{K}$ is in this case less than $2000 \mathrm{~km}^{3}$. In the original approach $(81)$, mean slope $(\alpha)$ is calculated as the arc tangent of $\Delta \mathrm{H}$ and the glacier length. However, as glacier length is not yet available for most of the glaciers in the study region, we here calculated mean slope by averaging for each glacier the slope values of all DEM cells. For glaciers with a constantly inclined surface there is no difference between the two ways of calculation, but for large valley glaciers with flat glacier tongues, the arc tangent calculation gives considerably smaller mean slopes than the DEM approach, which includes all the - mostly steeper - parts of the accumulation region. The DEM approach thus results in higher mean slope values and, hence, in much smaller volumes for large valley glaciers than the arc tangent approach. We thus calculated glacier volumes from the original approach with digitized flow lines (82) for a subset of 130 glaciers of different sizes and types in the western and central Himalaya. For this purpose calibrated the model with the thickness data of Dokriani Glacier (83), the only published data for the Himalaya besides Chhota Shigri Glacier in western Himalaya (40) and Kangwure Glacier in Tibet (84). This approach resulted in higher value for the glacier volume than for the mean slope from the DEM cells. The total volume would be about $2330 \mathrm{~km}^{3}$ (Table S2).

The second approach to estimating the glacier volume is the so-called volume-area scaling method (85). This method parameterizes glacier volume as a function only of glacier area. The scaling parameters are fitted to a relation between area and mean thickness, but for any given area the measured thicknesses vary widely, and so volume-area scaling is highly uncertain for individual glaciers. This is in particular the case for glaciers with multiple tributaries and avalanche-fed glaciers, both of which are common in the H-K. Moreover, in some of the inventories (CGI and the older ICIMOD inventories) rock outcrops are not mapped, resulting in often much too large glacier areas and hence an overestimation of the volume. Glacier volume resulting by applying several sets of scaling parameters as suggested by different studies (85-87) range from $\sim 3600$ to $\sim 6500 \mathrm{~km}^{3}$ (Table S2). Previous mass estimates based on older inventory data but the same parameterizations range from $\sim 4000$ to 
$\sim 8000 \mathrm{Gt}$ (which equals 4450 to $8900 \mathrm{~km}^{3}$ ) (50). The highest value resulting from the scaling parameters by $(87)$ are possibly overestimated because $(87)$ calibrate their volumearea scaling relationship on centerline mass losses of glaciers in Alaska. However, these values are likely overestimated (88). A further shortcoming is that none of the existing and applied scaling parameters were calibrated for Himalayan glaciers. However, all estimates are substantially higher than with the calculation based on (81), but clearly well below the estimate of $12,000 \mathrm{Gt}\left(\sim 13,300 \mathrm{~km}^{3}\right)$ presented in the Fourth Assessment Report of the IPCC (89). The wide range of the estimates indicates a pressing need for improved modeling approaches and for more in-situ thickness measurements for calibration and validation of the models. 


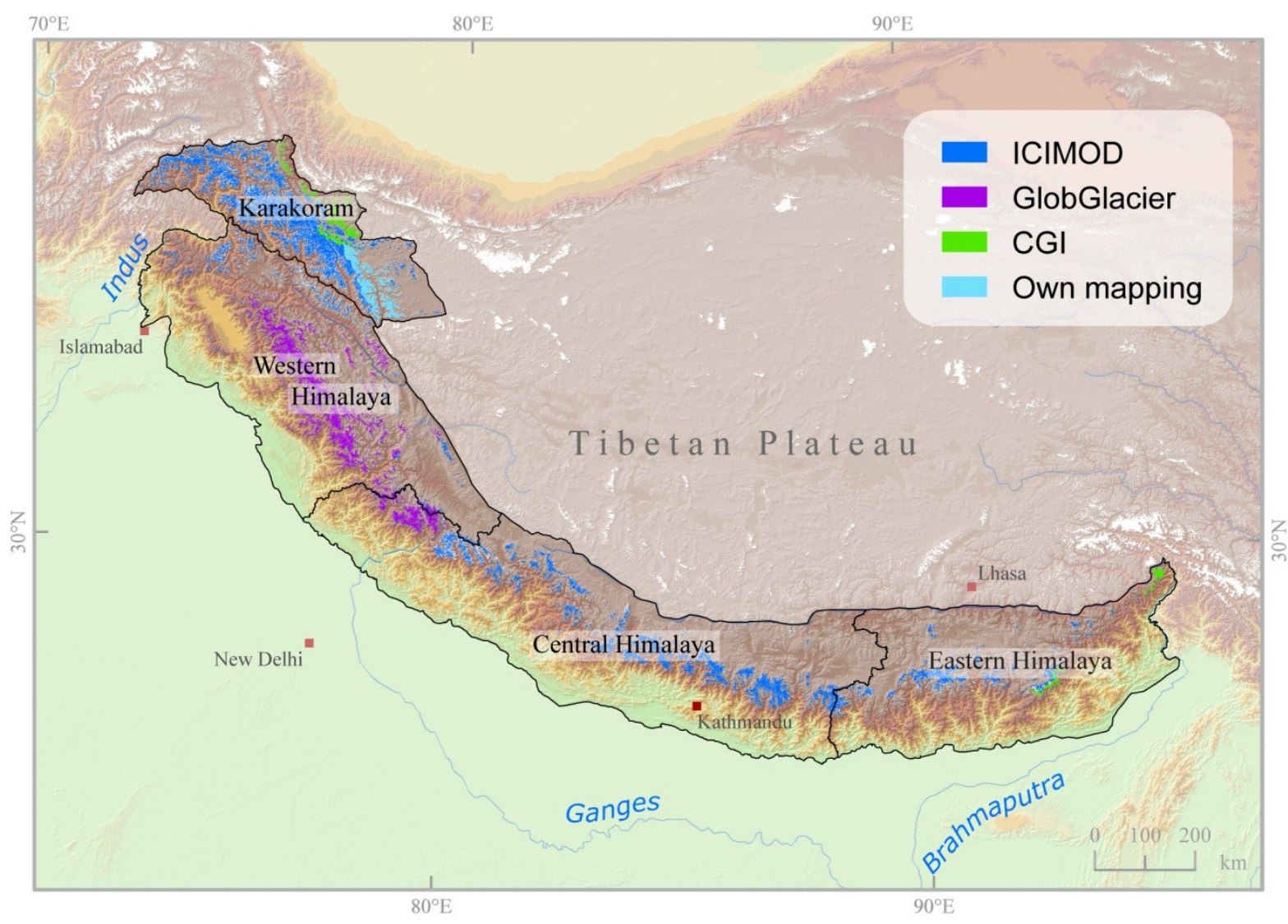

\section{Fig. S1.}

Sources of the Glacier Inventory of the Himalaya (ICIMOD (67), GlobGlacier $(68,69)$, CGI [Chinese Glacier Inventory] $(63,70)$, Own mapping: R. Bhambri). The figure shows also the subdivision into the four major regions. 


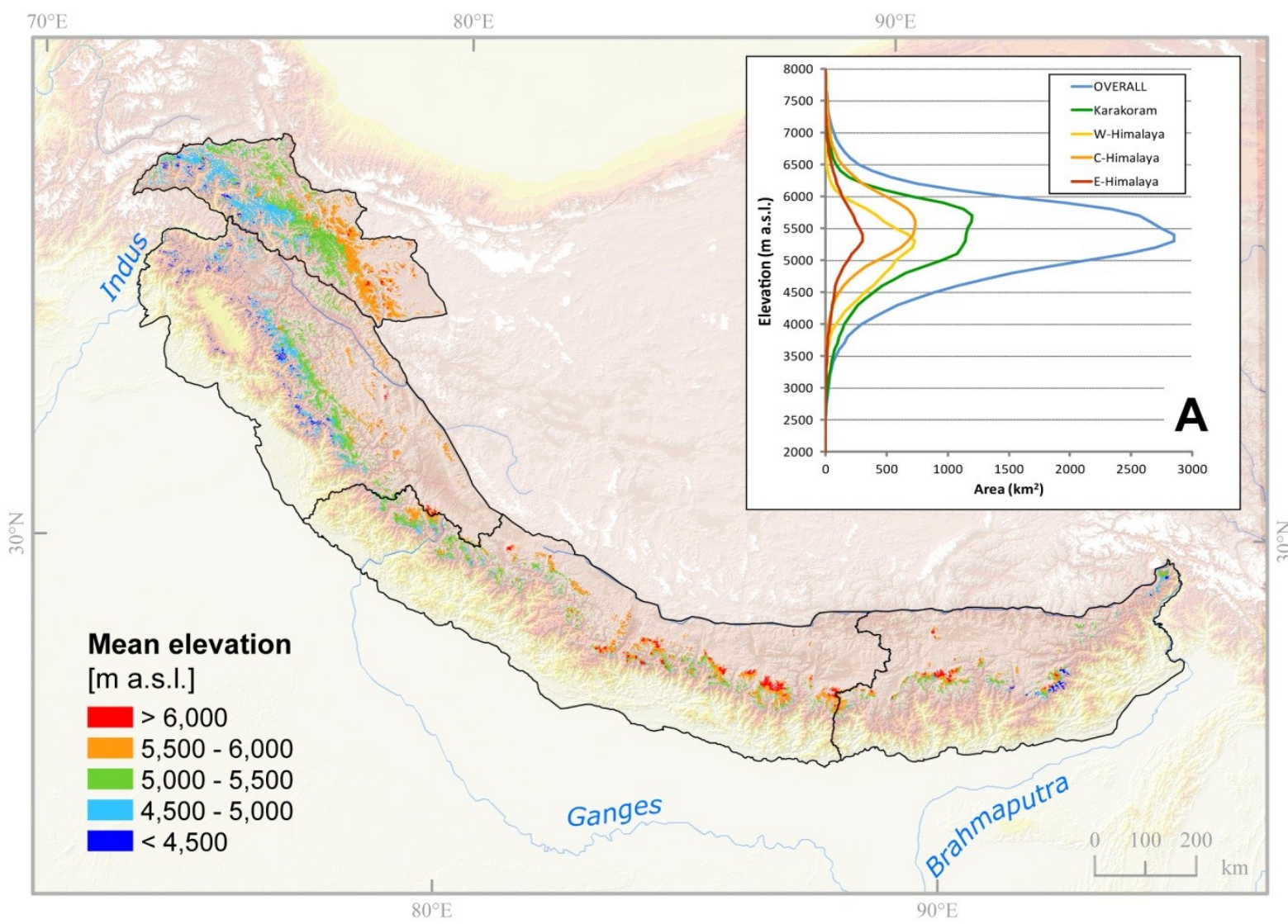

\section{Fig. S2}

Mean elevation of the glaciers in H-K. See also Table S2. As found in other mountain ranges, the mean elevations increase downwind, that is, with distance from the source of moisture. The glaciers in the northwest exposed to the westerlies are situated at comparatively low elevation, while the glaciers north or northeast of the main ridge of the Himalaya have a clearly higher mean elevation. A: Area-elevation distribution (hypsometry) for the different regions and for the whole of the H-K. The highest mean elevation of the Central Himalaya is noticeable. This distribution is bimodal: the higher and more explicit peak is probably due to the large area of high elevation glaciers northeast of the main ridge, the lower one due to those windward of the divide. The hypsometry for western Himalaya is strongly skewed towards lower elevations, probably due to high precipitation and possibly to debris cover promoting the survival of low lying glacier tongues. 


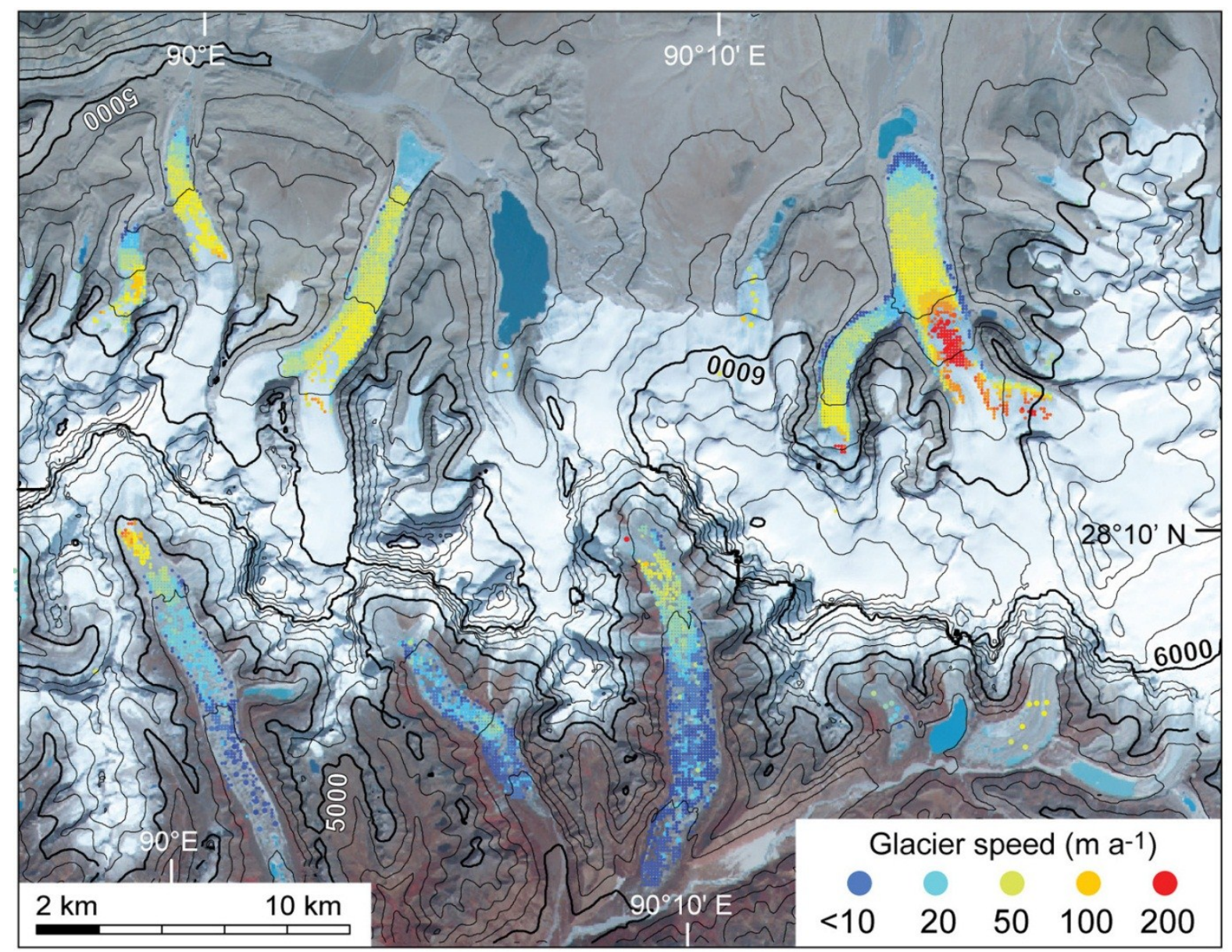

\section{Fig. S3}

Average annual horizontal surface speeds from ASTER data of 20 Jan 2001, 20 Nov 2001 and 22 Oct 2002 from normalized cross-correlation between the repeat images. Background image: ASTER channel 321 RGB composite of 20 Nov 2001. 200m-contours from the SRTM-DEM with voids filled using an ASTER DEM of 20 Jan 2001. Raw velocity measurements, with only a threshold on the correlation coefficient applied. Velocities 20 Jan20 Nov 2001 and 20 Nov 2001-22 Oct 2002 showed no significant differences. More information can be found in (26). 


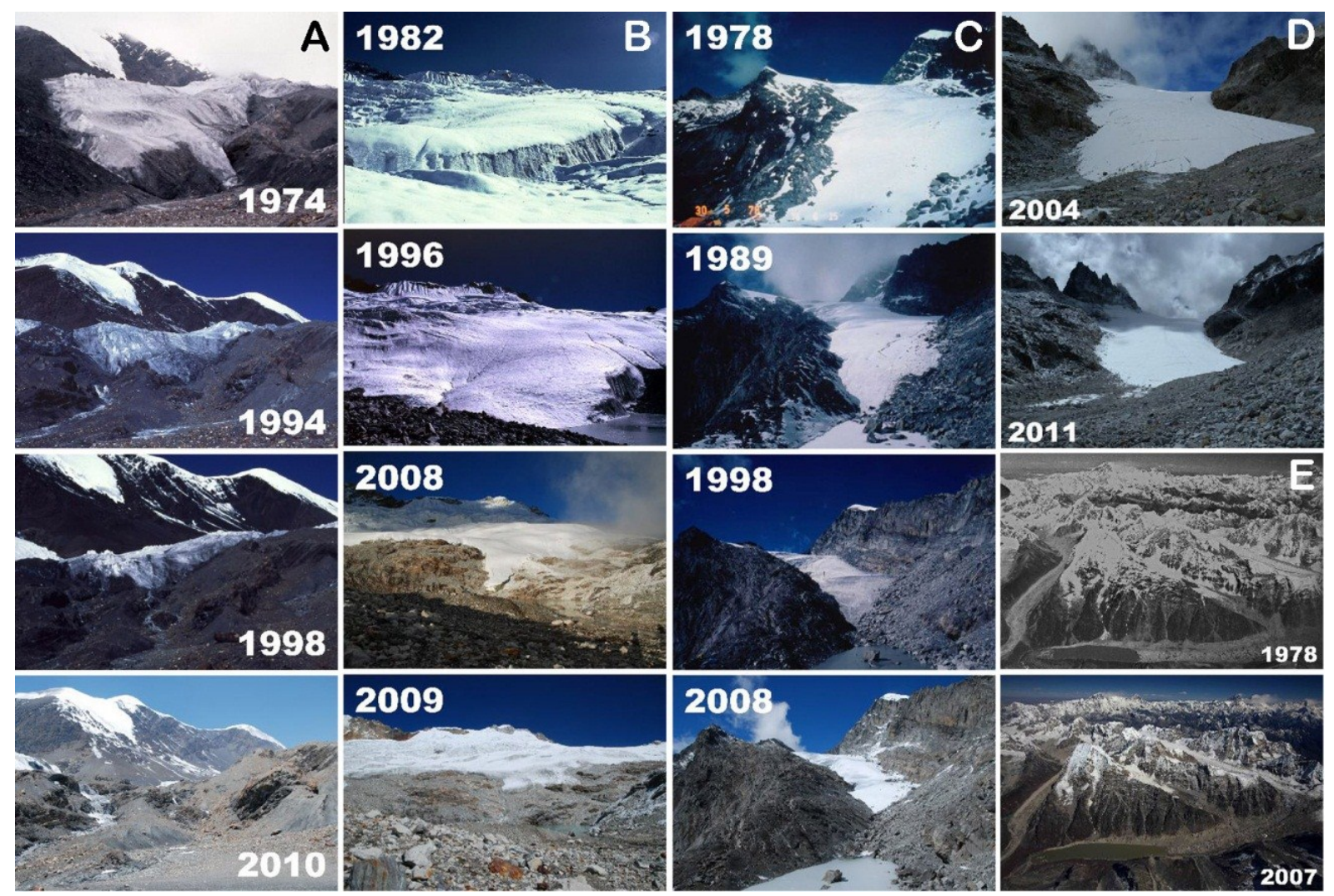

\section{Fig. S4}

Multi-temporal photo sequences showing the shrinkage of glaciers and (E) the concomitant development of a large glacial lake; A: Rikha Samba Glacier, Nepal; B: Yala Glacier, Nepal; C: Glacier AX010, Nepal; D: Ganju La Glacier, Bhutan; E: Tsho Rolpa, Nepal; Photos: GEN (Nagoya Univ. and Japanese Society of Snow and Ice), Y. Fujii, Y. Ageta, S. Kohshima, T. Kadota, K. Fujita and the Asahi Shimbun Company. 

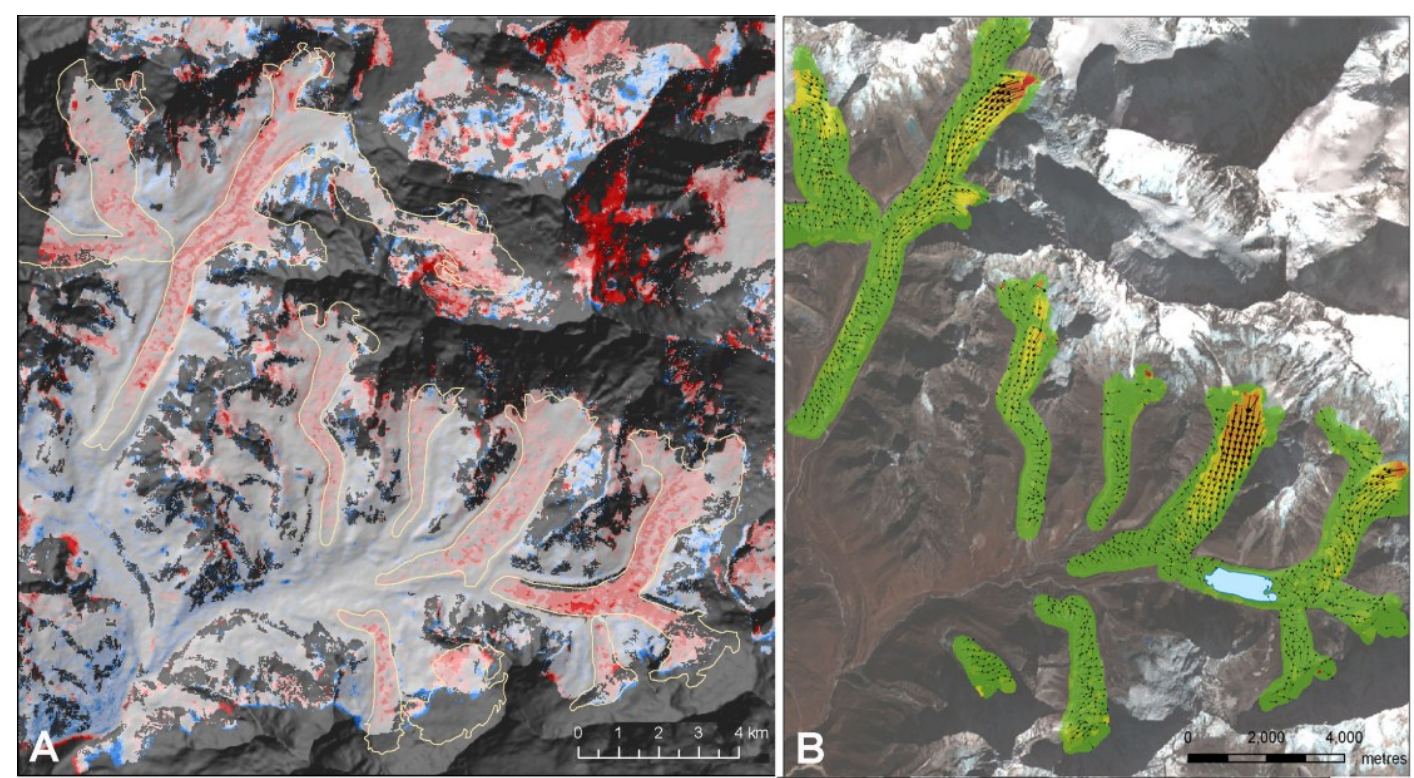

Legend

Surface velocity in [m/a]

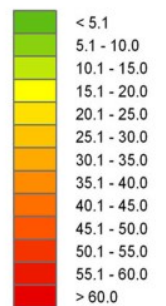

Flow direction and Flow direction and
surface velocity in [ $\mathrm{m} / \mathrm{a}$ ] $<10.1$ $10.1-20.0$ ! $\quad 20.1-30.0$

Glacier Deviation (m)

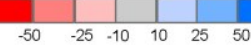

Fig. S5

Glacier elevation change (A) and velocity (B) for the glaciers south of Mt. Everest. Sources: $(20,90)$. For the location see Fig. 1. Background: shaded ASTER DEM (A) and ASTER RGB 321 composite (B). The elevation change was calculated by differencing of relatively adjusted DEMs based on Corona data (year 1970) and Cartosat-1 data (2007). The glacier velocity is derived using cross-correlation techniques based on ASTER data 20 Dec 2001 and 23 Nov 2003. The lower parts of the tongues show indications of stagnation (green color, undirected arrows, in B) similar to the southbound glaciers in Bhutan (Fig. S3). The red color, indicating mass loss, is clearly prevalent (in A). Only the upper clearly active parts of the glaciers and the distal parts show little or no lowering. The greatest surface lowering was found at Imja Glacier, where a pro-glacial lake has developed since the 1960s. The investigated glaciers, except one where no velocity measurements are available, are all heavily debris covered. More information can be found in $(20,90,91)$. 
Table S1: Published estimates of H-K glacier area. Note that the delineation of the regions varies as no clear boundary exists.

\begin{tabular}{|c|c|l|}
\hline Glacier area Himalaya $\left(\mathrm{km}^{2}\right)$ & Glacier area Karakoram $\left(\mathrm{km}^{2}\right)$ & Source \\
\hline 31,530 & 15,145 & $(92)$ \\
\hline 33,050 & 15,400 & $(3,65)$ \\
\hline 33,050 & 16,600 & $(60)$ \\
\hline 21,973 & 21,205 & $(50)$ \\
\hline 35,109 & n.a. & Qin, 1999 in $(93)$ \\
\hline
\end{tabular}

Table S2: Glacier statistics for the different regions. See section 2.2 for more information.

\begin{tabular}{|c|c|c|c|c|c|c|}
\hline & \multirow[t]{2}{*}{$\begin{array}{l}\text { Area } \\
\left(\mathrm{km}^{2}\right)\end{array}$} & \multirow{2}{*}{$\begin{array}{l}\text { Volume }\left(\mathrm{km}^{3}\right) \\
\text { based on }(81), \\
\text { adjusted }\end{array}$} & \multicolumn{3}{|c|}{$\begin{array}{l}\text { Volume }\left(\mathrm{km}^{3}\right) \text { based on scaling } \\
\text { parameters by }\end{array}$} & \multirow{2}{*}{$\begin{array}{l}\text { Mean } \\
\text { elevation } \\
\text { (m a.s.1.) }\end{array}$} \\
\hline & & & $(86)$ & $(85)$ & $(87)$ & \\
\hline Karakoram & 17,946 & 1259 & 2235 & 2745 & 4024 & 5326 \\
\hline $\begin{array}{l}\text { Western } \\
\text { Himalaya }\end{array}$ & 8943 & 415 & 515 & 610 & 895 & 5155 \\
\hline $\begin{array}{l}\text { Central } \\
\text { Himalaya }\end{array}$ & 9940 & 484 & 647 & 770 & 1128 & 5600 \\
\hline $\begin{array}{l}\text { Eastern } \\
\text { Himalaya }\end{array}$ & 3946 & 172 & 235 & 279 & 408 & 5395 \\
\hline $\begin{array}{l}\text { Himalaya } \\
\text { total }\end{array}$ & 22,829 & 1071 & 1397 & 1659 & 2431 & 5390 \\
\hline Total & 40,775 & 2330 & 3632 & 4403 & 6455 & 5362 \\
\hline
\end{tabular}


Table S3: Information about selected glaciers with length measurements. See Fig. 1 for the glacier locations.

\begin{tabular}{|c|c|c|c|c|c|c|c|}
\hline Abbr. & Glacier & Region & Period & $\begin{array}{l}\text { No. of } \\
\text { Measurements }\end{array}$ & $\begin{array}{l}\text { Mean Recession } \\
\text { Rate (m a-1) }\end{array}$ & Method & Reference \\
\hline SI & Mean of 26 Glaciers & Sikkim (East Himalaya) & $1976-2005$ & 4 & -12.2 & In-situ & (94) \\
\hline $\mathrm{AX}$ & AX010 & Shorong Himal (Central Himalaya) & 1978-1999 & 8 & -7.3 & In-situ & $(95,96)$ \\
\hline $\mathrm{CS}$ & Chhota Shigri & Himachal Pradesh (Western Himalaya) & $1961-2003$ & 3 & -23.3 & In-situ & $(22)$ \\
\hline SU & Sara Umga & Himachal Pradesh (Western Himalaya) & $1962-2004$ & 3 & -41.5 & In-situ & $(22)$ \\
\hline BS & Bara Shigri & Himachal Pradesh (Western Himalaya) & $1906-1995$ & 4 & -30.0 & In-situ & $(22)$ \\
\hline MI & Miyar & Himachal Pradesh (Western Himalaya) & $1961-1996$ & 4 & -17.1 & In-situ & $(22)$ \\
\hline ST & Samudra Tapu & Himachal Pradesh (Western Himalaya) & $1962-2000$ & 4 & -19.5 & In-situ, remote sensing & $(97)$ \\
\hline JA & Jaunder & Garhwal Himal (Central Himalaya) & 1959-1999 & 3 & -37.7 & In-situ & $(22)$ \\
\hline $\mathrm{JH}$ & Jhajju & Garhwal Himal (Central Himalaya) & 1959-1999 & 3 & -27.0 & In-situ & $(22)$ \\
\hline DO & Dokirani & Garhwal Himal (Central Himalaya) & $1960-2000$ & 3 & -16.4 & In-situ & $(22)$ \\
\hline ME & Meola & Garhwal Himal (Central Himalaya) & $1911-2000$ & 4 & -19.2 & In-situ & $(22)$ \\
\hline PI & Pindari & Garhwal Himal (Central Himalaya) & $1905-2001$ & 3 & -17.0 & In-situ & $(22)$ \\
\hline MIL & Milam & Garhwal Himal (Central Himalaya) & $1849-2006$ & 7 & -18.3 & In-situ & $(22,98)$ \\
\hline GA & Gangotri & Garhwal Himal (Central Himalaya) & $1842-2006$ & 10 & -13.6 & In-situ & $(22)$ \\
\hline $\mathrm{CT}$ & Chungpar-Tash & Nanga Parbat (Western Himalaya) & $1856-1987$ & 4 & -7.3 & In-situ & $(95)$ \\
\hline RA & Raikot & Nanga Parbat (Western Himalaya) & $1934-2007$ & 10 & -2.8 & Remote Sensing & (99) \\
\hline $\mathrm{CL}$ & Chogo Lungma & Karakoram & $1902-2010$ & 7 & -4.8 & In-situ & $(19,95)$ \\
\hline MIN & Minapin & Karakoram & $1989-2010$ & 10 & -12.6 & In-situ & $(19,95)$ \\
\hline GU & Ghulkin & Karakoram & $1980-2008$ & 11 & +4.3 & In-situ & (19) \\
\hline BA & Batura & Karakoram & $1860-2010$ & 9 & -5.0 & In-situ & (19) \\
\hline
\end{tabular}


Table S4: Selected studies with information about length changes for different regions or mountain chains in the Karakoram and surrounding regions. See Fig. 1 for the locations.

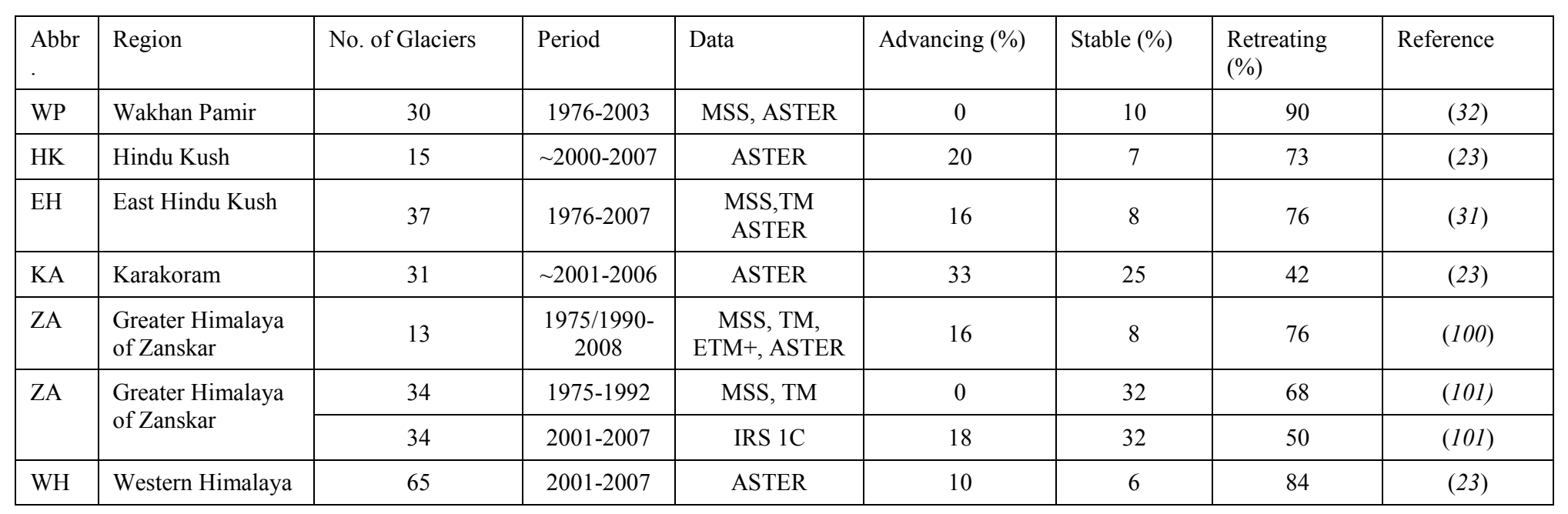


Table S5: Overview of existing studies of glacier area changes. See Figure 1 for the glacier locations.

\begin{tabular}{|c|c|c|c|c|c|c|c|c|c|c|}
\hline No. & $\begin{array}{l}\text { Catchment/ } \\
\text { Mountains }\end{array}$ & Region & $\begin{array}{l}\text { No. of } \\
\text { Glaciers }\end{array}$ & $\begin{array}{l}\text { Initial Area of } \\
\text { Glaciers }\left(\mathrm{km}^{2}\right)\end{array}$ & $\begin{array}{l}\text { Mean Glacier } \\
\text { size }\left(\mathrm{km}^{2}\right)\end{array}$ & Period & $\begin{array}{l}\text { Additional } \\
\text { survey }\end{array}$ & $\begin{array}{l}\text { Relative } \\
\text { Change (\% a- } \\
\text { 1) }\end{array}$ & Data source & Reference \\
\hline \multirow[t]{2}{*}{1} & Yarkant & Karakoram & 565 & 2707 & 4.8 & 1962-1999 & No & $-0.11 *$ & Map, Landsat ETM+ & (33) \\
\hline & Warwan & West Himalaya & 253 & 847 & 3.4 & $1962-2002$ & No & $-0.52 *$ & Map, IRS LISS-III & (35) \\
\hline 3 & Bhut & West Himalaya & 189 & 469 & 2.5 & $1962-2002$ & No & $-0.26^{*}$ & Map, IRS LISS-III & $(35)$ \\
\hline 4 & Chenab & West Himalaya & 359 & 1414 & 3.9 & $1962-2001$ & No & $-0.55^{*}$ & Map, IRS LISS-III & $(102)$ \\
\hline 5 & Kang Yatze & West Himalaya & 121 & 96.4 & 1.3 & 1969-2010 & 1991,2002 & $-0.35^{*}$ & $\begin{array}{l}\text { Corona, SPOT, Landsat, } \\
\text { WorldView }\end{array}$ & $(34)$ \\
\hline 6 & Zanskar & West Himalaya & 671 & 1023 & 1,5 & $1962-2002$ & No & $-0.23 *$ & Map, IRS LISS-III & $(35)$ \\
\hline 7 & Miyar & West Himalaya & 166 & 568 & 3.4 & $1962-2002$ & No & $-0.20^{*}$ & Map, IRS LISS-III & (35) \\
\hline 8 & Bhaga & West Himalaya & 111 & 363 & 3.3 & $1962-2002$ & No & $-0.75^{*}$ & Map, IRS LISS-III & (35) \\
\hline 9 & Chandra & West Himalaya & 116 & 696 & 6.0 & $1962-2002$ & No & $-0.51^{*}$ & Map, IRS LISS-III & (35) \\
\hline 10 & Parbati & West Himalaya & 90 & 493 & 5.5 & $1962-2004$ & No & $-0.50^{*}$ & Map, IRS LISS-IV & (35) \\
\hline 11 & Baspa & West Himalaya & 19 & 173 & 9.1 & $1962-2001$ & No & $-0.49^{*}$ & Map, IRS LISS-III & $(103)$ \\
\hline \multirow[t]{2}{*}{12} & Bhagirathi 1 & Central Himalaya & 13 & 275 & 21.2 & $1968-2006$ & 1990 & $-0.09 \pm 0.07$ & Corona, ASTER & $(36)$ \\
\hline & Bhagirathi 2 & Central Himalaya & 212 & 1345 & 6.3 & $1962-2002$ & No & $-0.31 *$ & Map, IRS LISS-III & $(35)$ \\
\hline 13 & Alaknandra & Central Himalaya & 69 & 325 & 4.7 & $1968-2006$ & 1990 & $-0.15 \pm 0.07$ & Corona, ASTER & $(36)$ \\
\hline 14 & Gori Ganga & Central Himalaya & 41 & 335 & 8.2 & $1962-2002$ & No & $-0.49 *$ & Map, IRS LISS-III & $(35)$ \\
\hline 15 & Naimona'nyi & West Himalaya & n.n. & 84.4 & n.n. & $1976-2003$ & 1990,1999 & $-0.31^{*}$ & $\begin{array}{l}\text { Landsat MSS, TM, } \\
\text { ASTER }\end{array}$ & $(106)$ \\
\hline 16 & NW Nepal & Central Himalaya & n.n. & n.n. & nn. & $1980-2000$ & No & $\sim-0.8^{*}$ & $\begin{array}{l}\text { Map, Corona, Landsat } \\
\text { ETM+ }\end{array}$ & $(107)$ \\
\hline \multirow[t]{2}{*}{17} & Gandaki & Central Himalaya & 1071 & 2030 & 1.9 & $\sim 1970-2009$ & No & $-0.91 * *$ & Map, Landsat ETM+ & $(39)$ \\
\hline & Karnali & Central Himalaya & 1361 & 1739 & 1.3 & $\sim 1970-2009$ & No & $-0.29 * *$ & Map, Landsat ETM+ & $(39)$ \\
\hline 18 & $\begin{array}{l}\text { Ghyirong } \\
\text { Zangbo }\end{array}$ & Central Himalaya & n.n. & 418 & n.n. & $1976-2006$ & 1988 & $-0.58 *$ & Landsat MSS, TM & $(38)$ \\
\hline 19 & Poiqu & Central Himalaya & n.n. & 304 & n.n. & $1976-2006$ & 1988 & $-0.54 *$ & Landsat MSS, TM & $(38)$ \\
\hline 20 & Pengqu & Central Himalaya & n.n. & 2056 & n.n. & $1976-2006$ & 1988 & $-0.48 *$ & Landsat MSS, TM & $(38,108)$ \\
\hline \multirow[t]{3}{*}{21} & Koshi & Central Himalaya & 779 & 1413 & 1.8 & $\sim 1970-2009$ & No & $-0.42 * *$ & Map, Landsat ETM+ & $(39)$ \\
\hline & Dudh Koshi & Central Himalaya & 20 & 92 & 4.6 & $1962-2005$ & 1992,2002 & -0.12 & $\begin{array}{l}\text { Corona, Landsat TM, } \\
\text { ASTER }\end{array}$ & $(104)$ \\
\hline & Dudh Koshi & Central Himalaya & 40 & 404 & 10.1 & 1960-1992 & No & $-015^{*}$ & Maps & $(105)$ \\
\hline 22 & $\begin{array}{l}\text { Mt. Everest } \\
\text { north }\end{array}$ & Central Himalaya & n.n. & n.n. & n.n. & $1974-2008$ & 1990 & $-0.30 *$ & Map, ASTER & $(108)$ \\
\hline 23 & Tista & East Himalaya & 57 & 402 & 7.1 & $1997-2004$ & No & -0.36 & LISS-III & (35) \\
\hline 24 & Lunana & East Himalaya & 66 & 147 & 2.2 & 1963-1993 & No & $-0.30 *$ & Map, SPOT & (37) \\
\hline
\end{tabular}

* Uncertainty not given or data is based on medium resolution satellite data or on topographic maps of which the quality was not investigated. **Highly uncertain as data is based on maps and the first date can be estimated only roughly. 


\section{Table S6: Glaciers or regions with available measurements of mass budget in the H-K region}

a Average mass-budget rate; uncertainty is given only when estimated in the source

b Glac: glaciological (in-situ) measurements; Geod: geodetic (in-situ or remote-sensing) surveys of elevation change multiplied by average density; AAR: mapping of the accumulation-area ratio by remote sensing; Hydr: hydrological method.

\begin{tabular}{|c|c|c|c|c|c|c|}
\hline Region & Glacier Name & $\begin{array}{l}\text { Mass Budget Data } \\
\text { estimation (years) }\end{array}$ & $\begin{array}{l}\text { Years of observation } \\
\text { (periods) }\end{array}$ & $B\left(\mathrm{~m} \text { w.e. } \mathrm{a}^{-1}\right)^{a}$ & Method $^{b}$ & Reference \\
\hline & Changme Khangpu & 1979-1982 & 4 & -0.16 & Glac & $(94)$ \\
\hline & AX010 & 1979; 1996-1999 & 5 & $-0.61 \pm 0.09$ & Glac & $(95,96)$ \\
\hline & AX010 & $1978-2008$ & $30(4)$ & $-0.75 \pm 0.09$ & Geod & $(44)$ \\
\hline & Mt. Everest region $\left(62 \mathrm{~km}^{2}\right)$ & $1970-2007$ & $37(2)$ & $-0.32 \pm 0.08$ & Geod & $(20)$ \\
\hline & Khumbu & $1962 ; 1970-2007$ & $37(4)$ & $-0.27 \pm 0.08$ & Geod & $(20)$ \\
\hline & Dokriani & $1992-2000$ & 6 & -0.32 & Glac & $(109)$ \\
\hline & Dokriani & 1963-1995 & $32(1)$ & -0.32 & Geod & $(109)$ \\
\hline & Chorabari & $2004-2007$ & 4 & -0.74 & Glac & $(94)$ \\
\hline & Naradu & $2000-2003$ & 3 & -0.40 & Glac & $(110)$ \\
\hline & Dunagiri & $1984-1990$ & 6 & -1.04 & Glac & $(94)$ \\
\hline & Tipra Bank & 1981-1989 & 6 & -0.29 & Glac & $(94)$ \\
\hline & Nehnar & $1975-1984$ & 9 & -0.54 & Glac & $(94)$ \\
\hline & Gara & 1974-1982 & 8 & -0.37 & Glac & $(94)$ \\
\hline & Gor Garang & $1976-1985$ & 9 & -0.43 & Glac & $(94)$ \\
\hline & Shaune Garang & 1981-1991 & 10 & -0.36 & Glac & $(94)$ \\
\hline & Chhota Shigri & $2002-2010$ & 8 & $-0.67 \pm 0.40$ & Glac & $(40)$ \\
\hline & Hamtah & 2001-2006 & 6 & -1.60 & Glac & $(112)$ \\
\hline & Lahaul/Spiti $\left(915 \mathrm{~km}^{2}\right)$ & 1999-2004 & $5(1)$ & -0.70 to -0.85 & Geod & $(41)$ \\
\hline & Baspa basin (19 glaciers) & $2001-2006$ & 4 & -0.69 & AAR & $(35)$ \\
\hline \multicolumn{7}{|c|}{ Karakoram } \\
\hline & Siachen & 1986-1991 & 5 & -0.51 & Hydr & $(42)$ \\
\hline & Central Karakoram $\left(5615 \mathrm{~km}^{2}\right)$ & 1999-2008 & $9(1)$ & $+0.11 \pm 0.22$ & Geod. & (43) \\
\hline
\end{tabular}


Table S7: Conditions, characteristics, and contributions of the three major H-K river catchments and the contribution of glacier melt water to the overall discharge based on different sources.

\begin{tabular}{|c|c|c|c|c|c|}
\hline No. & Parameter & Indus Basin & Ganges Basin & $\begin{array}{l}\text { Brahmaputra } \\
\text { Basin }\end{array}$ & Source \\
\hline \multirow[t]{3}{*}{1} & \multirow[t]{3}{*}{ Total Area $\left(\mathrm{km}^{2}\right)$} & $1,081,718$ & $1,016,124$ & 651,335 & $(113)$ \\
\hline & & $1,139,814$ & $1,023,609$ & 527,666 & $(2)$ \\
\hline & & $1,005,786$ & 990,316 & 525,797 & $(1)$ \\
\hline 2 & $\begin{array}{l}\text { Upstream Area (\%> } \\
2000 \mathrm{~m} \text { asl.) }\end{array}$ & 40 & 14 & 68 & (1) \\
\hline \multirow[t]{2}{*}{3} & \multirow[t]{2}{*}{ Glacier area } & 8926 & 16,677 & 4366 & Qin, 1999 in (113) \\
\hline & & 20,325 & 12,659 & 16,118 & (2) \\
\hline 4 & No. of glaciers & 5057 & 6694 & 4366 & Qin, 1999 in (113) \\
\hline 5 & Ice Volume & 850 & 1971 & 600 & Qin, 1999 in (113) \\
\hline \multirow[t]{2}{*}{6} & \multirow{2}{*}{$\begin{array}{l}\text { Glaciated area ( } \% \text { of } \\
\text { total area) }\end{array}$} & 0.8 & 1.2 & 0.7 & $\mathrm{~L} 3 / \mathrm{L} 1$ \\
\hline & & 1.78 & 1.24 & 3.05 & $(2)$ \\
\hline 7 & $\begin{array}{l}\text { Glaciated area (\% of } \\
\text { upstream area }>2000 \\
m \text { asl.) }\end{array}$ & 2.2 & 1.0 & 3.1 & (1) \\
\hline 8 & $\begin{array}{l}\text { Annual precipitation } \\
\text { basin (mm) }\end{array}$ & 423 & 1,035 & 1,071 & (1) \\
\hline 9 & $\begin{array}{l}\text { Upstream } \\
\text { precipitation (\%) }\end{array}$ & 36 & 11 & 40 & (1) \\
\hline \multirow[t]{3}{*}{10} & \multirow{3}{*}{$\begin{array}{l}\% \text { glacier melt to } \\
\text { overall run-off }\end{array}$} & Up to $50 \%$ & $\sim 9 \%$ & $\sim 12 \%$ & $(93)$ \\
\hline & & $>30 \%$ & $>5 \%$ & $<10 \%$ & $(1)$ \\
\hline & & 1.40 & 0.33 & 0.41 & $(2)$ \\
\hline 11 & $\begin{array}{l}\text { \% glacier melt to } \\
\text { overall run-off } \\
\text { (upstream) }\end{array}$ & 11.6 & 13.8 & 2.3 & (2) \\
\hline \multirow[t]{3}{*}{12} & \multirow[t]{3}{*}{ Population $\left(10^{3}\right)$} & 178,483 & 407,466 & 118,543 & $(113)$ \\
\hline & & 209,619 & 477,937 & 62,421 & $(1)$ \\
\hline & & 211,280 & 448,980 & 62,430 & $(2)$ \\
\hline 13 & $\begin{array}{l}\text { Net irrigation water } \\
\text { Demand }\end{array}$ & 908 & 716 & 480 & (1) \\
\hline
\end{tabular}




\section{References}

60. J. F. Shroder, in Encyclopedia of Snow, Ice and Glaciers, V. P. Singh, P. Singh, U. K. Haritashya, Eds. (Springer Science+Business Media, Dordrecht, 2011), pp. 510-519.

61. H. Gurung, Mountains of Asia: A Regional Inventory (ICIMOD, Kathmandu, Nepal, 1999).

62. P. K. Mool, S. R. Bajracharya, S. P. Joshi, Inventory of Glaciers, Glacial Lakes, Glacial Lake Outburst Floods: Monitoring and Early Warning Systems in the Hindu KushHimalayan Region, Nepal (ICIMOD, Kathmandu, Nepal, 2001).

63. Y. Shi, C. Liu, E. Kang, The Glacier Inventory of China. Ann. Glaciol. 50, 1 (2009).

64. B. Raup et al., The GLIMS geospatial glacier database: A new tool for studying glacier change. Global Planet. Change 56, 101 (2007). doi:10.1016/j.gloplacha.2006.07.018

65. M. Dyurgerov, M. Meier, Mass balance of mountain and subpolar glaciers: A new global assessment for 1961-1990. Arct. Alp. Res. 29, 379 (1997). doi:10.2307/1551986

66. L. Dolgushin, G. Osipova, Ledniki (Glaciers) (Mysl’ Press, Moscow, 1989).

67. S. R. Bajracharya, B. R. Shrestha, Eds., The Status of Glaciers in the Hindu KushHimalayan Region (ICIMOD, Kathmandu, Nepal, 2011).

68. F. Paul et al., GlobGlacier: A new ESA project to map the world's glaciers and ice caps from space. EARSeL eProceedings 8, 11 (2009).

69. H. Frey, Compilation and Applications of Glacier Inventories using Satellite Data and Digital Terrain Information (Zurich, 2011).

70. X. Li., GLIMS Glacier Database, Boulder, CO, National Snow and Ice Data Center/World Data Center for Glaciology, Digital Media, 2003

71. D. K. Hall, G. A. Riggs, V. V. Salomonson, Development of methods for mapping global snow cover using moderate resolution imaging spectroradiometer data. Remote Sens. Environ. 54, 127 (1995). doi:10.1016/0034-4257(95)00137-P

72. A. E. Racoviteanu, F. Paul, B. Raup, S. J. S. Khalsa, R. Armstrong, Challenges and recommendations in mapping of glacier parameters from space: Results of the 2008 Global Land Ice Measurements from Space (GLIMS) Workshop, Boulder, Colorado, USA. Ann. Glaciol. 50, 53 (2010). doi:10.3189/172756410790595804

73. F. Paul, A. Kääb, Perspectives on the production of a glacier inventory from multispectral satellite data in Arctic Canada: Cumberland Peninsula, Baffin Island. Ann. Glaciol. 42, 59 (2005). doi:10.3189/172756405781813087

74. F. Paul, A. Kääb, M. Maisch, T. Kellenberger, W. Haeberli, The new remote-sensingderived Swiss glacier inventory: I. Methods. Ann. Glaciol. 34, 355 (2002). doi:10.3189/172756402781817941

75. T. Bolch, B. Menounos, R. D. Wheate, Landsat-based inventory of glaciers in western Canada, 1985-2005. Remote Sens. Environ. 114, 127 (2010). doi:10.1016/j.rse.2009.08.015

76. T. Bolch, M. F. Buchroithner, A. Kunert, U. Kamp, in GeoInformation in Europe, M. A. Gomarasca, Ed. (Millpress, Netherlands, 2007), pp. 403-410.

77. R. Bhambri, T. Bolch, R. K. Chaujar, Mapping of debris-covered glaciers in the Garhwal Himalayas using ASTER DEMs and thermal data. Int. J. Remote Sens. 32, 8095 (2011). doi:10.1080/01431161.2010.532821

78. T. Bolch, U. Kamp, Glacier mapping in high mountains using DEMs, Landsat and ASTER data. Grazer Schriften der Geographie und Raumforschung 41, 13 (2006). 
79. F. Paul, C. Huggel, A. Kääb, Combining satellite multispectral image data and a digital elevation model for mapping debris-covered glaciers. Remote Sens. Environ. 89, 510 (2004). doi:10.1016/j.rse.2003.11.007

80. T. Strozzi, F. Paul, A. Kääb, in Proceedings of the ESA Living Planet Symposium 2010, 28 June to 2 July 2010, Bergen, Norway, SP-686, DVD, pp. 4.

81. W. Haeberli, M. Hoelzle, Application of inventory data for estimating characteristics of and regional climate-change effects on mountain glaciers: a pilot study with the European Alps. Ann. Glaciol. 21, 206 (1995).

82. F. Paul, A. Linsbauer, Modeling of glacier bed topography from glacier outlines, central branch lines, and a DEM. Int. J. Geogr. Inf. Sci. 2012, (2012). doi:10.1080/13658816.2011.627859

83. J. T. Gergan, D. P. Dobhal, R. Kaushik, Ground penetrating radar ice thickness measurements of Dokriani Bamak (glacier), Garhwal Himalaya. Curr. Sci. 77, 169 (1999).

84. L. Ma, L. Tian, J. Pu, P. Wang, Recent area and ice volume change of Kangwure Glacier in the middle of Himalayas. Chin. Sci. Bull. 55, 2088 (2010). doi:10.1007/s11434-0103211-7

85. D. B. Bahr, M. F. Meier, S. D. Peckham, The physical basis of glacier volume-area scaling. J. Geophys. Res. 102, (B9), 20,355 (1997). doi:10.1029/97JB01696

86. J. Chen, A. Ohmura, Estimation of Alpine glacier water resources and their change since 1870s. IAHS Publication 193, 127 (1990).

87. A. A. Arendt et al., Updated estimates of glacier volume changes in the western Chugach Mountains, Alaska, and a comparison of regional extrapolation methods. J. Geophys. Res. 111, (F3), F03019 (2006). doi:10.1029/2005JF000436

88. E. Berthier, E. Schiefer, G. K. Clarke, B. Menounos, F. Rémy, Contribution of Alaskan glaciers to sea-level rise derived from satellite imagery. Nat. Geosci. 3, 92 (2010). doi:10.1038/ngeo 737

89. IPCC, Climate Change 2007 - The Physical Science Basis; Working Group I: Contribution to the Fourth Assessment Report of the Intergovernmental Panel on Climate Change (Cambridge Univ. Press, 2007).

90. T. Bolch, M. F. Buchroithner, J. Peters, M. Baessler, S. R. Bajracharya, Identification of glacier motion and potentially dangerous glacial lakes in the Mt. Everest region/Nepal using spaceborne imagery. Nat. Hazards Earth Syst. Sci. 8, 1329 (2008). doi:10.5194/nhess-8-1329-2008

91. T. Pieczonka, T. Bolch, M. Buchroithner, Generation and evaluation of multitemporal digital terrain models of the Mt. Everest area from different optical sensors. ISPRS J. Photogramm. 66, 927 (2011). doi:10.1016/j.isprsjprs.2011.07.00359.

92. H. von Wissmann, Die heutige Vergletscherung und Schneegrenze in Hochasien. Abh. Math. Nat. KI. Akad. Wiss Mainz 14, 1103 (1959).

93. M. Eriksson et al., The Changing Himalayas: Impact of Climate Change on Water Resources and Livelihoods in the Greater Himalayas (ICIMOD, Kathmandu, Nepal, 2009).

94. V. Raina, Himalayan Glaciers, a state-of-art review of glacial studies, glacial retreat and climate change, Discussion Paper, Ministry of Environment and Forests, New Delhi, India (2009).

95. World Glacial Monitoring Service, Fluctuation of Glaciers 2000-2005 (Vol. IX), ICSU (FAGS)/IUGG (IACS)/UNEP/UNESCO/WMO (WGMS, Zürich, 2008). 
96. K. Fujita, T. Kadota, B. Rana, R. B. Kayastha, Y. Ageta, Shrinkage of Glacier AX010 in Shorong region, Nepal Himalayas in the 1990s. Bull. Glaciol. Res. 18, 51 (2001).

97. A. V. Kulkarni, S. Dhar, B. P. Rathore, R. K. B. Govindha, R. Kalia, Recession of Samudra Tapu Glacier, Chandra River Basin, Himachal Pradesh. J. Indian Soc. Remote Sens. 34, 39 (2006). doi:10.1007/BF02990745

98. K. B. G. Raj, Recession and reconstruction of Milam Glacier, Kumaon Himalaya, observed with satellite imagery. Curr. Sci. 100, 1420 (2011).

99. S. Schmidt, M. Nüsser, Fluctuations of Raikot Glacier during the past 70 years: a case study from the Nanga Parbat massif, northern Pakistan. J. Glaciol. 55, 949 (2009). doi:10.3189/002214309790794878

100. U. Kamp, M. Byrne, T. Bolch, Glacier fluctuations between 1975 and 2008 in the Greater Himalaya Range of Zanskar, southern Ladakh. J. Mt. Sci. 8, 374 (2011). doi:10.1007/s11629-011-2007-9

101. A. C. Pandey, S. Ghosh, M. S. Nathawat, Evaluating patterns of temporal glacier changes in Greater Himalayan Range, Jammu \& Kashmir, India. Geocarto Int. 26, 321 (2011). doi:10.1080/10106049.2011.554611

102. A. V. Kulkarni et al., Glacial retreat in Himalaya using Indian Remote Sensing satellite data. Curr. Sci. 92, 69 (2007).

103. A. V. Kulkarni, S. Alex, Estimation of recent glacial variations in Baspa basin using remote sensing technique. J. Indian Soc. Remote Sens. 31, 81 (2003). doi:10.1007/BF03030775

104. T. Bolch, M. F. Buchroithner, T. Pieczonka, A. Kunert, Planimetric and volumetric glacier changes in the Khumbu Himal, Nepal, since 1962 using Corona, Landsat TM and ASTER data. J. Glaciol. 54, 592 (2008). doi:10.3189/002214308786570782

105. F. Salerno, E. Buraschi, G. Bruccoleri, G. Tartari, C. Smiraglia, Glacier surface-area changes in Sagarmatha National Park, Nepal, in the second half of the 20th century, by comparison of historical maps. J. Glaciol. 54, 738 (2008). doi:10.3189/002214308786570926

106. Q. Ye, T. Yao, S. Kang, F. Chen, J. Wang, Glacier variations in the Naimona'nyi region, western Himalaya, in the last three decades. Ann. Glaciol. 43, 385 (2006). doi:10.3189/172756406781812032

107. R. Frauenfelder, A. Kääb, Glacier mapping from multi-temporal optical remote sensing data within the Brahmaputra river basin. in Proc. 33rd Int. Symposium on Remote Sensing of Environment, 4-8 May 2009, Stresa, Italy (2009), Paper 299, 4 pp.

108. Q. Ye et al., Monitoring glacier and supra-glacier lakes from space in Mt. Qomolangma region of the Himalayas on the Tibetan Plateau in China. J. Mt. Sci. 6, 211 (2009). doi:10.1007/s11629-009-1016-4

109. D. Dobhal, J. Gergan, R. J. Thayyen, Mass balance studies of the Dokriani Glacier from 1992 to 2000, Garhwal Himalaya, India. Bull. Glaciol. Res. 25, 9 (2008).

110. M. Koul, R. Ganjoo, Impact of inter- and intra-annual variation in weather parameters on mass balance and equilibrium line altitude of Naradu Glacier (Himachal Pradesh), NW Himalaya, India. Clim. Change 99, 119 (2010). doi:10.1007/s10584-009-9660-9

111. M. Kaul, Mass balance of Liddar glaciers. Trans. Inst. Indian Geogr. 8, 95 (1986).

112. World Glacial Monitoring Service, Glacier Mass Balance Bulletin 10, updated and earlier issues, ICSU (FAGS)/ IUGG (IACS)/ UNEP/UNESCO /WMO (WGMS, Zurich, 2009). 
113. J. Xu, A. B. Shrestha, R. Vaidya, M. Eriksson, K. Hewitt, The Melting Himalayas: Regional Challenges and Local Impacts of Climate Change on Mountain Ecosystems and Livelihoods" ICIMOD Technical Paper (ICIMOD, Kathmandu, Nepal, 2007). 